\title{
The Other Gates: Anglo-American Influences on and from Dublin
}

\author{
Charlotte Purkis
}

This chapter extends the established historical narrative of the relationship between the London and Dublin Gate Theatres. It elaborates on the impact that the London Gate Studio Theatre's management made on the foundation of the Dublin Gate Studio Theatre in 1928, reviews unpublished documentary evidence which points to the under-researched influence of London Gate co-director Velona Pilcher (1894-1952) and seeks to clarify London Gate director Peter Godfrey's (1899-1970) role in relation to the Dublin theatre. In keeping with the emphasis of this volume on cultural convergence, a brief account follows about the development and activities of two other theatres - one in England and one in the US - which were, like the Dublin Gate, also inspired by the London Gate and connected back to it through the two London co-directors working within new partnerships. The lost stories of these other theatres founded in the 1940s are valuable, since they suggest a shared sense of avant-garde sensibility in English-speaking theatre which is surprisingly cohesive across an otherwise unconnected group. The 'Gate Theatre

\footnotetext{
C. Purkis $(\bowtie)$

University of Winchester, Winchester, UK

e-mail: Charlotte.Purkis@winchester.ac.uk

(C) The Author(s) 2021

O. Pilný et al. (eds.), Cultural Convergence, https://doi.org/10.1007/978-3-030-57562-5_5
} 
Studio' opened in Hollywood (Los Angeles) in 1943 (supported by Godfrey), while the Watergate Theatre Club opened in London in 1949 (supported by Pilcher); they each closed during the Edwards - mac Liammóir era of the Dublin Gate. Print media picked up on connections to the original London Gate from re-use of the name, circulating these apparent links in magazine articles and newspaper reports.

Although Godfrey had been in the market for transferring and exchanging productions to extend his sphere of operation beyond London in the late twenties and early thirties, no network of the separate establishments discussed in this chapter was ever formally developed. Yet Godfrey was credited in his lifetime, at the time of his death, and in recently published reference texts with the founding of all three Gate Theatres. For example in 1954, World Biography Volume 5 listed under his name: 'Founded The Gate Theatre, London, Dublin and Hollywood' (433). Subsequently, Godfrey is recorded as having founded the Dublin Gate in at least one obituary published in the US in March 1970: Variety called him 'a native of London' who 'founded The Gate Theatre there and Dublin' ('Obituaries: Peter Godfrey' 79). In Britain, The Stage and Television Today obituary does not mention Dublin, but does record that in Hollywood he 'opened another Gate theatre in 1943' ('Obituary: Peter Godfrey' 11). The misconception about his role with the Dublin Gate may well have stemmed from reminiscences related to the publicity surrounding the 1943-1945 Hollywood Gate Theatre venture, the reputation of the Dublin Gate from its American tours, and perhaps also because American drama featured strongly in the Dublin Gate programming, further connecting the two countries. The past association with Dublin may have been highlighted because the Dublin Gate was more renowned around the world than the only distantly-remembered London Gate and the barely-known Hollywood Gate. The error that associated Godfrey with the founding of the Dublin Gate is still being perpetuated. In Terry Rowan's current Who's Who in Hollywood it is claimed that Godfrey was 'a stage actor, producer and director in England and Ireland' (137). While it is true that Godfrey had travelled to Ireland as a youth when he performed as a clown and conjuror with Swift's Circus ('Peter Godfrey' 345), he had not even personally produced his adaptation of William Pratt's nineteenth-century melodrama Ten Nights in a Bar Room, or Ruined by Drink when it was performed at the Dublin Gate in May 1930. On 26 January 1938, he directed an Irish play on Broadway, Shadow and Substance by Paul Vincent Carroll, which had just 
come from the Abbey Theatre; arguably, to the media, this would have further consolidated an Irish connection, especially as the play won the New York Drama Critics' Circle award in this production.

Parallels can be drawn between the collaborative work at the various Gate venues and their club cultures, although these other venues and associated companies operated independently from one another. Looking comparatively at the missions of these Gate Theatres raises awareness of how cultural connections and parallel enthusiasms gave rise to similar conceptual formulations across mid-twentieth-century experimental theatre culture.

\section{The London Gate}

The London Gate began as the 'Gate Salon' in the upstairs of a dilapidated warehouse at 38 Floral Street, Covent Garden on 30 October 1925. This first theatre was founded by Peter Godfrey and his then wife Molly Veness. Both acted in the productions, as the theatre was an ensemble venture. Its ethos was that theatre was 'The Gate to Better Things'. Godfrey was publicly praised in the press for what he was achieving. In September 1927, G.W. Bishop from The Era called him an 'artist of the theatre' whose work had 'imagination and vision' and who 'has shown us what can be done with the smallest of stages and the leanest of resources' (5). Godfrey was consistently the chief producer and managing director, but he relied on a number of business/artistic partnerships as the Gate developed and expanded. Godfrey's second partnership was with AngloAmerican thespian Velona Pilcher who was willing to invest money and also a range of expertise in journalism, engraving and printing, and arts management. ${ }^{1}$ She became his new co-director in March 1927 when Veness retired from active management, and the Salon location closed. Pilcher apparently paid for Godfrey's contribution to the new premises so that they could work together on an equal footing, handing over $£ 800$ which represented the whole of her capital (Sprigge 53). This partnership was short-lived and lasted for the 1927-1928 'third' season, although Pilcher's influence continued into the start of 1928-1929. It resulted in rebranding from 'Salon' to a 'Studio', in a new venue at Villiers Street, Charing Cross, and in artistic development of illustrated programmes and a logo.

The Godfrey-Pilcher partnership has been overlooked in the majority of published histories of the London Gate, although published and 
unpublished documentation from the time exists which verifies its existence. ${ }^{2}$ Their association developed the theatre and its audience considerably due to its new venue, and the introduction of playbills, programmes, and publicity photographs of the productions which were also occasionally picked up by the press contributed to greater attention to the theatre's productions than in its Floral Street days, and greater financial success. In February 1928, Ashley Dukes wrote in the international magazine Theatre Arts Monthly in his role as London correspondent concerning the re-opening: 'I believe this experiment is the most hopeful that London has seen since the War, and possibly the most important.' (145) He also commented on the significance of the name: 'The Gate Theatre modestly made it clear that it was a strait and narrow Gate, like the eye of a needle, through which the prosperous and contented men of the theatre would find it exceedingly difficult to pass.' (144) Pilcher herself enthused in Theatre Arts Monthly in an article about her work there how the Gate was 'an independent house' addressing 'itself to the present-day intelligence, eager to participate - all energies on edge - in contemporary creative work' $(1929,509)$.

The Gate was a club theatre throughout its history, which meant that audience members were subscribers (who paid an annual fee in order to be eligible to buy tickets) and the theatre could bypass censorship law and thus the processes of the Lord Chamberlain's Examiner of Plays, so long as it did not sell tickets to non-members. One of the reasons that the Godfrey-Pilcher partnership came under strain was due to the 1928 court case which claimed that the club status had been violated by these arrangements breaking down and fined the co-directors. Pilcher appears to have been forced out of the Gate when their association started to break down in summer 1928 under the strain of these proceedings. An unpublished biography by Pilcher's partner at the time of her death, Elizabeth Sprigge, 'L'Idiote Illuminée: The Life and Writing of Velona Pilcher', written with access to Pilcher's journals and letters then in her possession, recorded Godfrey's position in his argument with Pilcher, how he had refused to sign the partnership agreement set up by Pilcher and her solicitor in 1927 as he had not agreed with two of her terms: 'Naturally enough', commented Sprigge, 'as it was he who had started the original Gate in Floral Street and made its considerable reputation, he felt that if the partnership ended, the name "Gate Theatre Studio" should become his property. In addition, he wanted the lease of the premises, which had been taken in his name, to remain his property' (54), and how 
he had taken it for granted that 'she would be willing to be bought out' (63). Although Pilcher had physically left her regular work at the Gate by winter 1928 , her influence pervaded the theatre into its fourth season, 1928-1929, because it had been her role to choose the plays, and some of the programme notes continuing to be printed may well have been hers. ${ }^{3}$

In January 1929, Charles N. Spencer became the new partner to Godfrey, who was quick to issue a new subscription leaflet excluding mention of Pilcher and reasserting himself as 'the foremost producer of the New Theatre in this country' and stating that 'it is purely as a result of his [Godfrey's] technical knowledge and abilities that The Gate Theatre has now an international reputation and remains the only advanced theatre in England' (1). Recalling the Gate in the 1930s, the distinguished London theatre critic, J.C. Trewin, described the theatre under Godfrey as 'steadily and challengingly esoteric' and a 'rebel's haven' $(1960,62)$. The theatre changed under its subsequent director, Norman Marshall, who despite remaining in partnership with Charles N. Spencer was initially less successful but then re-established the venue as a revue theatre which also produced new plays. Andrew Davies's account of Marshall's takeover stated that Godfrey sold the theatre to Marshall for $£ 2500$ and that Godfrey was apparently exhausted (90). The Manchester Guardian recorded the financial failure of Godfrey's Gate in August 1933 and stated that it was due to a lack of reserves, declining membership and an unsuccessful arrangement 'for the periodical exchange of plays and companies' with the Cambridge Festival Theatre which had been discontinued in January 1933 ('The Gate Theatre' 10). But Godfrey moved on very successfully into a range of other employment: as a popular compère and magician at the London Pavilion variety theatre, then into broadcasting as a producer for Anglo-foreign programmes, followed by film acting and directing.

In his valedictory announcement to members, Godfrey had summarized his achievement as 'giving London a chance of seeing the amazing experiments that were being made in the theatre all over central Europe and in America just after the war' (Marshall 50). Marshall was responsible for establishing the history of the theatre in a well-circulated account of the British 'little theatre movement', The Other Theatre (1947). Marshall of course had an interest in consolidating the strong reputation because he had been the last owner of the theatre which has been consistently recognized since in theatre histories as a groundbreaking organization for introducing experimental Western theatre from Europe and the US 
to British audiences and for paving the way for many of the plays first produced there to achieve success in wider circulation. Trewin summed up its importance in 1960 by remarking how there, it had been possible to see 'many of the foreign plays which would not otherwise have reached London' (235). More recently, Jozefina Komporaly has defined the London Gate as 'a translation powerhouse' and 'one of the most daring institutions of the inter-war British theatre scene', and undertaken a detailed examination of the Gate's internationalist 'vocation' and 'mission' (129). Marshall's Gate closed in 1941 when it was hit by a bomb during the Blitz.

\section{Familiar Narratives Concerning the Foundation of the Dublin Gate Reviewed}

A review of the historicization of the founding narrative of the Dublin Gate needs to go back to the late 1920s and also to extend to the present day. As well as primary documentary resources, such as press reports and subscription literature from the theatre, there are also vital anecdotal reminiscences in published memoirs. Connections between the London and Dublin Gates were outlined in several press reports. In 1929, the Derry Journal noted that ' $[\mathrm{t}]$ he Dublin Gate Theatre is similar in aims and objects to the London Gate Theatre and produces what it considers the best modern plays wherever written' ('From the Irish Capital' 3). Theatre Arts Monthly linked the theatres in a commentary by Dukes, who was very familiar with the London Gate and observed that the new Dublin theatre's playhouse was 'at least three times as large as that of its London namesake' $(1930,383)$. In the same magazine in July 1931, St. John Ervine mentioned the situation in Dublin in 'The Plight of the Little Theatre': 'In Dublin, in addition to the Abbey Theatre, which seems to be in a period of fallow, two littler theatres contrive to obtain audiences: the Peacock and the Gate (The latter began in admitted imitation of the Gate Theatre in London, but is now developing a character of its own).' (545)

In published accounts from the 1930s, less emphasis was placed on London. Bulmer Hobson recorded in his early history The Gate Theatre Dublin (1934) that the theatre was founded 'in association with the Gate Theatre Studio' (12), but also confirmed that 'in actual practice its association or connection with the other organisation in England entirely ceased with these initial conversations' (14). By 1939, the Irish Times 
reported on a lecture to the Dublin Literary Society given by Mr. Andrew E. Malone, which had surveyed 'Ten Years of the Gate Theatre: What it Has Done for Drama'. No mention at all was made of any impact or influence from the London Gate. In fact, the view expressed was that ' $\mathrm{t}] \mathrm{he}$ way had been prepared for the coming of the Gate Theatre by the Dublin Drama League and by a number of excellent amateur societies'. The independence of Ireland was rammed home with this remark: 'When it was contended that Dublin audiences knew nothing of European and American dramatists before the opening of the Gate Theatre, the contention was without ground, as most of the great contemporary dramatists had their work offered in Dublin, often before even London had seen it.' ('Ten Years of the Gate Theatre' 15)

Modernist experimentation in theatre practice has been seen as the key link between the two Gates. But the London Gate's advocacy for theatrical innovation and reputation for promoting new continental plays was actually only one facet of the impetus for the development of modernist drama in Dublin. Others of significance which occurred earlier were the productions of Yeats's plays at the Abbey from the 1910s-20s, and the foundation of the Dublin Drama League (1918-1928), to which 'the experimental roots of both the Peacock and the Gate theatres can be traced' because of the way 'the appetite for experimentalism' was 'so well fostered' by that organization (Sisson 2011, 39, 52). The introduction of German expressionist plays to audiences in London and Dublin began in the mid-twenties and was simultaneous in both places. The audience for experimental drama was sparked in Dublin by the 1925 Abbey Theatre production by Arthur Shields of Vera Mandel's translation of Ernst Toller's Masses and Man (1921).

The influence of the expressionism experienced in London on Denis Johnston is recorded in the interview by Hickey and Smith, 'Did You Know Yeats?', in which Johnston spoke about what he and Sean O'Casey had 'discovered together in the London Gate Theatre' ('Johnston' 62). The experience led to Johnston's production of Georg Kaiser's expressionist play From Morn to Midnight (1916), which he would have seen in Godfrey's staging at the London Gate in 1925. Johnston's From Morn to Midnight was presented at the Peacock Theatre in 1927 under the umbrella of the Abbey Theatre by the 'New Players' for the Dublin Drama League. Elaine Sisson has discussed the expressionist productions witnessed by Johnston at the London Gate as a radical departure which had opened his eyes to 'the potential of theatre as an expressive medium' 
(2010, 138). Subsequently, Virginie Girel-Pietka has built on this work to consider in detail how production elements taken from the experience of watching Toller's Masses and Man (1920) at the Gate Salon in 1926 impressed Johnston and fed into his own work (112-13).

In his memoir All for Hecuba (1947), mac Liammóir recalled his partner Hilton Edwards's 'flying visit to London from which he returned full of his talks with Peter Godfrey', whom Edwards had first befriended when he acted alongside Godfrey in the Forum Theatre Guild production by Robert Atkins of The Dybbuk at The Royalty Theatre, London (4 April 1927). Mac Liammóir went on to liken Godfrey's achievements in London to adding a new taste to the repertoire of those less exotic English supper dishes which he compared to various more regular theatrical experiences: 'Godfrey was building a reputation for his methods of production and for the choice of his plays, which had a certain quality as of caviare, and filled a real gap in the English theatrical menu.' (58) Edwards's account, in a later interview from the early 1970s, recalled how Godfrey was persuasive about a close relationship between London and Dublin and reported that when he had 'told Peter Godfrey about our project he said: "Why a new theatre? Why not start another Gate and we can exchange plays?"' ('Edwards and Mac Liammoir' 77). Irish writer Sean Dorman's autobiography Portrait of My Youth (1992) repeated this claim and elaborated: 'the idea was that they should be of benefit to one another. He [Godfrey] was to act for them as a clearing house for interesting Continental plays, and they in their turn were to send him new material.' (154)

Revisiting the established narrative of the Dublin Gate's origins, including the initial intentions for connection with the London Gate, benefits from historiographical reflection on how the narrative has been repackaged by the recycling of extant information in the public domain across secondary accounts. The various similarities in retellings have led to an accepted familiarity, arguably contributing to a lack of ongoing interrogation. Historiographical reading of the layering of the inherited story within secondary source accounts, which looks into how a history has been written and what the influences on the story have been, can expose how and why retellings are repetitious. But the variety of reformulations within these repetitions can also contribute to rethinking a range of dimensions characterizing the theatre's outlook, recognizing that these are informed by notions of the avant-garde established throughout the retellings of this history. 
In later twentieth-century versions and rewritings of the foundation of the Dublin Gate, Godfrey is often seen as a father figure and his London theatre as an inspiration and productive influence. In 1978, Robert Hogan reviewed and commented on the primary documentary sources of the history of the foundation, reproducing the four-page circular distributed to selected Dublin potential theatregoers in the mail on 15 September 1928, which identified the inspiration from London:

It is proposed to open the Dublin Gate Theatre Studio in October, 1928 , for the production of modern and progressive plays, unfettered by theatrical convention. The London Gate Theatre has been extraordinarily successful, and the directors of the Dublin Gate Theatre are in a position to avail themselves of this organisation for procuring plays that would not otherwise be within the reach of Dublin Theatrical circles. (13)

A reference made to extra activities also responds to the innovations introduced in the third season of the London Gate: 'It is hoped to hold from time to time lectures, discussions, and exhibitions of painting for the benefit of members.' (13) Hogan commented that the 'list of possible productions [...] proposed, was for Dublin a rather dazzling prospect indeed' (14).

In other sources, there has not been a conclusive shift away from making any meaningful connection at all, but there has been a growing tendency to play down or omit influence from London. Even in the mid-century the Irish Times' report on Denis Johnston's talk about the history of the Gate on Raidió Éreann in 1953 claimed that 'he did not say who thought of "Gate" and made no mention of English influence ('Denis Johnston Reviews' 5). Explaining that when 'Edwards and Mac Liammóir founded the Dublin Gate Theatre in 1928 they kept alive this international impulse within the Irish theatre' (112), Hogan bypassed any mention of an influence from London in his 1967 study of Irish theatre (although he did acknowledge it in his subsequent study of the Gate in 1978 as cited above). Elaine Sisson's detailed investigation of the emergence of theatrical modernism in Ireland within Ireland, Design and Visual Culture: Negotiating Modernity, 1922-1992 relegates the London connection to a footnote: 'The Gate Theatre Dublin (1928), took its name from the Gate, London, an indication that, by association, the Dublin Gate was aiming to be as daring and experimental as its London counterpart.' $(2011,270)^{4}$ Some current texts ignore 
the London connection altogether. This might have been otherwise had the London Gate Theatre continued into post-war times. ${ }^{5}$ The histories published this century generally suggest that the relationship between the theatres was not actually that meaningful. Christopher Morash diminished the link, placing the reference in brackets, and saying that the name, the Gate Theatre '(originally intended to indicate a vague affiliation with Peter Godfrey's Gate Theatre in London's Covent Garden)' (178). Christopher Murray expressed the connection as: 'Modelled to some extent on Peter Godfrey's Gate Studio theatre in London, which O'Casey admired' (212). Then in 2010, Thomas Connolly re-emphasized Edwards and mac Liammóir's intention to create 'a Dublin version of the London Gate Theatre's avant-garde style' with its 'unlicensed and experimental English and European plays', adding emotion into the retelling by declaring: 'Impressed by the productions they saw' at The London Gate Studio Theatre 'they determined to do the same' (71-72). The approach taken seems to depend on the context for the author's focus, so in The Cambridge Companion to Irish Modernism, Ben Levitas chooses to ignore any role of the London Gate, writing that the Dublin Gate was the Dublin Drama League's 'natural successor' in keeping with his account that highlights national modernist experiments in Ireland (120).

\section{Links Between the Gates: Projected} Programming, Exchange of Plays and the Circulation of Key Theatrical Personnel

Although it came to be the case that the connections between the theatres were not to be as may have first been thought, the initial plans are historically relevant to a discussion of origins and influences. Initially, a London aspect shows in the programming proposed for Dublin's first season, which maps onto the programme developed by the GodfreyPilcher partnership at the Gate. ${ }^{6}$ A suggested list of plays projected for Dublin appeared in subscribers' publicity - a four-page circular from the 'Dublin Gate Theatre Studio' by its four directors: 'Hilton Edwards, Micheál Mac Liammóir, Gearóid O Lochlainn and D. Bannard Cogley'. Of that list, these, which had all been produced in the London Gate, did not in fact get produced: Maya (London Gate Studio, 22 November 1927), Nju (London Gate Salon, 19 July 1926, and Studio, 14 June 1928), Orphée (London Gate Studio, 11 April 1928), All 
God's Chillun (London Gate Studio, 20 November 1928) and Simoom (London Gate Salon, 11 October 1926). The plan appears to respond to the conversations Edwards had had with Godfrey about contemporary avant-garde theatre, and also to conform to reports made by some historians that Edwards had planned 'an exchange-of-plays scheme with Godfrey' (Cowell 8). However, Edwards later claimed: 'We exchanged only one play'; 'although our association remained very friendly, there was really no connection between the theatres' ('Edwards and Mac Liammoir' 77). The exchange which did occur was Godfrey's burlesque adaptation of Pratt's Ten Nights in a Bar Room, which opened at the London Gate on 1 January 1930, and which the Dublin Gate staged in a production of their own a few months later in May 1930. It was extremely popular in both venues. ${ }^{7}$

The following were also produced in both places in different productions: The Theatre of the Soul (London, 19 October 1927; Dublin, 12 December 1928), The Hairy Ape (London, 26 January 1928; Dublin, 28 October 1928) and Six Stokers Who Own the Bloomin' Earth (London, 5 July 1928; Dublin, 2 January 1929). With respect to the second production of the new company at the Peacock, O'Neill's The Hairy Ape (1922), Bulmer Hobson's history recorded the admiration of Edwards for Godfrey's 1928 London set: a 'superb conception' which 'directly influenced' and 'coloured' their treatment for the Dublin production (25). Ian $\mathrm{R}$. Walsh has pointed to this as an example of influence on Edwards as a director that 'should not be missed' because the borrowed approach was successfully used again (31). Perhaps surprisingly, bearing in mind this initial confluence of productions of the same plays, Edwards recalled later that plays 'suited to [Godfrey] were not really suited to us' ('Edwards and Mac Liammoir' 77). Sean Dorman quoted another recollection by Edwards: that he (Edwards) had not realized in the late twenties 'that the distance that separated us was much greater than the geographical one. We got pulled apart. He [Godfrey] asked me only to safeguard and keep to ourselves the name of "Gate Theatre".' (154) Edwards also retrospectively commented, 'I rather regret that we called it the Gate', although he acknowledged that it had seemed a good idea at the time, and also emphasized that they had survived longer than the London Gate, thus outliving potentially interconnected history ('Edwards and Mac Liammoir' 77).

There was a further link which tangentially connected the two theatres and their conjoined history: Terence Gray, the director of the Cambridge Festival Theatre (founded in 1925) who was the son of an Irish aristocrat. 
In 1931-1932, Gray trialled an experimental notion of theatrical collaboration between locations, aiming to set up a cartel in England, aping that of 'des Quatres' in Paris. That was a group of theatres which the Gate in London was inspired by and which influenced its programming (Komporaly 136). Godfrey had got involved successfully with Gray as a producer, and he directed several plays in Cambridge in 1928, around the time that he was enthusing Edwards about a possible collaboration between the Gates: Kaiser's From Morn to Midnight in February, a new American play by Elmer Rice, The Subway, on 5 November and Eugene O'Neill's The Hairy Ape on 26 November. Ultimately, Gray's attempt to try to link the Gate Theatre London to the Festival Theatre Cambridge failed, although the cooperation had been enthusiastically presented as a new departure by Gray in The Festival Review and then announced in Theatre Arts Monthly. Drama magazine reported in 1932 that an arrangement between the theatres had started, and that Peter Godfrey had directed and acted in his own 'potted version' of Ibsen's Peer Gynt, which opened in Cambridge ( 7 October) and then transferred with the same cast to London (18 October) at the Gate Theatre ('Plays of the Month' 29). And The Stage also recorded the arrangement having started and that there was now a 'Cartel company' who 'pass from Villiers Street to Cambridge and back again' ('The Gate: Peer Gynt' 12). According to Rowell and Jackson, the association did not last because 'the needs and organisation of the two proved too disparate for close cooperation' (64). It is also reported as failing because of the international financial crisis of the early 1930s, a context which Davies records in his discussion of Gray's plans. According to Davies, Gray had purchased a site in Covent Garden and intended to build a new theatre there, but even with his 'drive and administrative flair' he was defeated by the difficult circumstances (88-89).

Gray was also connected to Anmer Hall (A.B. Horne) who had worked with him in Cambridge as a student. In 1934, Hall invited the Gate Theatre Dublin company to perform at the Westminster Theatre, London, and again in 1937. According to the account by Grene and Morash in Irish Theatre on Tour, as impresario of this venue Hall manifested 'the same artistic policy as Edwards and Mac Liammoir, and as Peter Godfrey's pioneering Gate Theatre in London', which was 'the presentation of new and experimental work' (162). A further associate of Gray was his cousin, the Irish dancer Ninette de Valois, born Edris Stannis, who had as a child attended the same performing arts school 
- the Lila Field Academy London - as mac Liammóir, born Alfred Willmore (Sorley Walker 6). The Peacock Theatre in Dublin was influenced by Gray's experimental festival theatre in Cambridge due to W.B. Yeats's interest and familiarity with it (Sisson 2011, 43). Richard Allen Cave has detailed in Collaborations (201la) de Valois's meeting with Yeats at Cambridge and her collaboration with him at the Peacock in the late 1920s supporting the productions of his Noh plays. She also started the Abbey school of ballet there in 1928 .

Billed as the first production in the British Isles, Oscar Wilde's Salomé produced by the Dublin Gate company was performed at the Peacock Theatre, Dublin on 12 December 1928. De Valois was not involved, but she choreographed the 'dance of the seven veils' for Gray's Salomé productions in Cambridge twice, in 1929 and 1931, and did a third choreography to music by Constant Lambert for Godfrey's production starring Margaret Rawlings for the London Gate Studio (27 May 1931), and then performed the same choreography herself at the Camargo Society (Cave 2011b, 151). Salomé thus became another play that was produced at both Gates, in a different production in each location as was the case with the other shared repertoire. But in this case, it was the Dublin Gate who produced it first. Joan FitzPatrick Dean has commented that this production of Salomé demonstrated the attraction of the Dublin theatre to evading censorship, and this was something else it had in common with the London Gate (129). De Valois worked alongside Marshall who was also within Gray's experimental theatre circle at the same time, and when Gray abandoned theatre life in 1933, relinquishing the Festival Theatre in June, Norman Marshall was able to offer several of those who had worked with him new opportunity at the London Gate as its new owner. In this capacity, it might have been possible for Marshall to invite the Dublin players there, but that did not happen. ${ }^{8}$

\section{Hitherto Unrecognized Influence}

New flavour is added to the story of the Dublin Gate's foundation by reminiscence, recorded within Sprigge's biography, of Pilcher's involvement, raising new questions about her role in connecting the London and Dublin Gates. ' According to Sprigge, while 'in the little theatre' (the Gate) in London, 'one successful play followed another and its reputation soared [...] it was at this time that Hilton Edwards consulted [Pilcher] about the formation of the Dublin Gate' (63). This was the late summer 
of 1928. All that is known about this conversation is that Pilcher "was firm in her view that it must be affiliated in its policy to the parent theatre' (Sprigge 64). There is no further documentary evidence of the connection.

However, visual evidence points to ideas in common that seem to be prompted by Pilcher. Pilcher's artistic vision for the London Gate Studio appears to have had a greater impact on the Dublin Gate than has yet been considered and is a valuable addition to its early history. Similarity between the logos for the two Gates reveals that Pilcher may have influenced the famous design for Dublin made by mac Liammóir. It is not possible to be completely certain who designed the Gate Theatre Studio London logo because it is unsigned and no archival evidence has been discovered, but it began to be used in the third season and Pilcher was the key influence on the introduction of visual arts to the theatre. It is possible this is by Pilcher because all the other engravings used by the theatre are signed and the logo is drawn in a different style to the majority of the images on the programmes which were made by Blair Stanton-Hughes, a former fellow student of Pilcher's. Pilcher had studied art and was associated with Leon Underwood's art school in Girdler's Road, where she signed up as a member on her return to London from the Continent in 1921. The Underwood group, including Pilcher, had a significant interest in wood-engraving. If it is not made by her, then it is certainly a logo that she endorsed, because she personally supervised the production of all the playbills and notices initially through Robert Gibbings' Press and then the Gate Press which was located in her own cottage. Sprigge reported that Pilcher was 'determined to make it [the Gate] a centre of modern art' (55). It is not hard to imagine that Edwards returned to Dublin with copies of Pilcher's theatre programmes which carried her logo (Figs. 5.1 and 5.2).

The conversation Edwards held with Pilcher could have been then as equally influential as the discussions reported back to mac Liammóir with Godfrey. Arguably, Pilcher had a greater influence on the choice of plays of the London Gate's third and fourth seasons than Godfrey, judging from what is recorded in the British press of the time about her, and what she wrote about her time working at the theatre herself. Bishop stated categorically in The Era in his portrait of Godfrey, 'A Youthful Producer', that ' $[\mathrm{t}]$ he selection of plays will be under the direction of Velona Pilcher, who during the last two or three years has visited Prague, Paris, Berlin, Moscow and the little theatres of America, studying the 


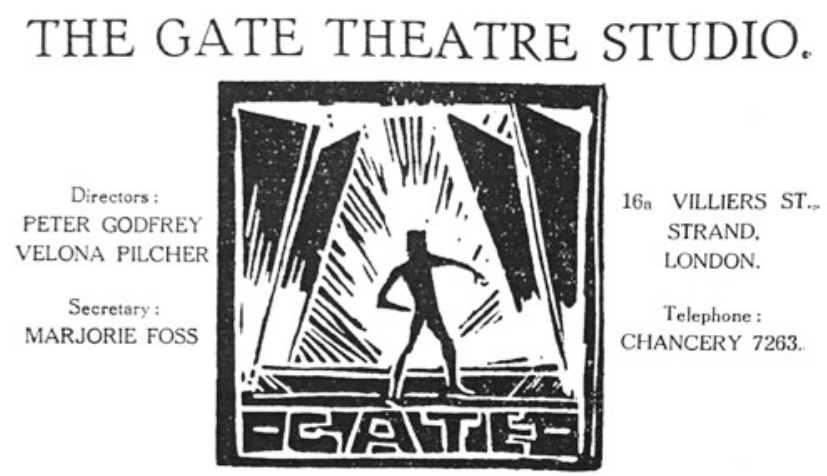

The Gate Theatre Studio is a private Little Theatre and seats for its performances may only be bought by Members, for themselves and their friends.

Members of the Studio are also entitled to use the Theatre as a club room after half-past-four in the afternoons, between which time and the opening of the evening's play tea and sandwiches will be served, and books and writing material will be available.

Fig. 5.1 Pilcher's (?) logo used at the London Gate Studio on programmes, leaflets and letters 1927-1929, shown here on the 'Subscriber's Leaflet' 1927 announcing the new theatre

work of the younger school of dramatists'. He also took the opportunity to praise her articles in the American Theatre Arts Monthly which he declared to have admired (5). And J.T. Grein reinforced her importance to the newly launched Gate Studio, describing her enthusiastically as a 'world pilgrim in quest of plays' with 'a formidable list' the same autumn in The Illustrated London News (192).

In her article about her time as selector of plays, 'No Work and All Play' (July 1929), Pilcher wrote about these experiences and set out her priorities for the contemporary stage. It is the 1927-1928 season that most influenced the programming in Dublin. So, it may then not be a coincidence that the Dublin Gate staged Back to Methuselah in an epic production in its new Rotunda over three nights on 23-25 October 1930, as this work had featured on her list of priorities. Prior to her 1929 article appearing, Pilcher had been invited onto the BBC radio in November 1928 to broadcast her thoughts in the series engineered by James Agate 'The Aims and Ideals of the Theatre'. She was one of an impressive group 


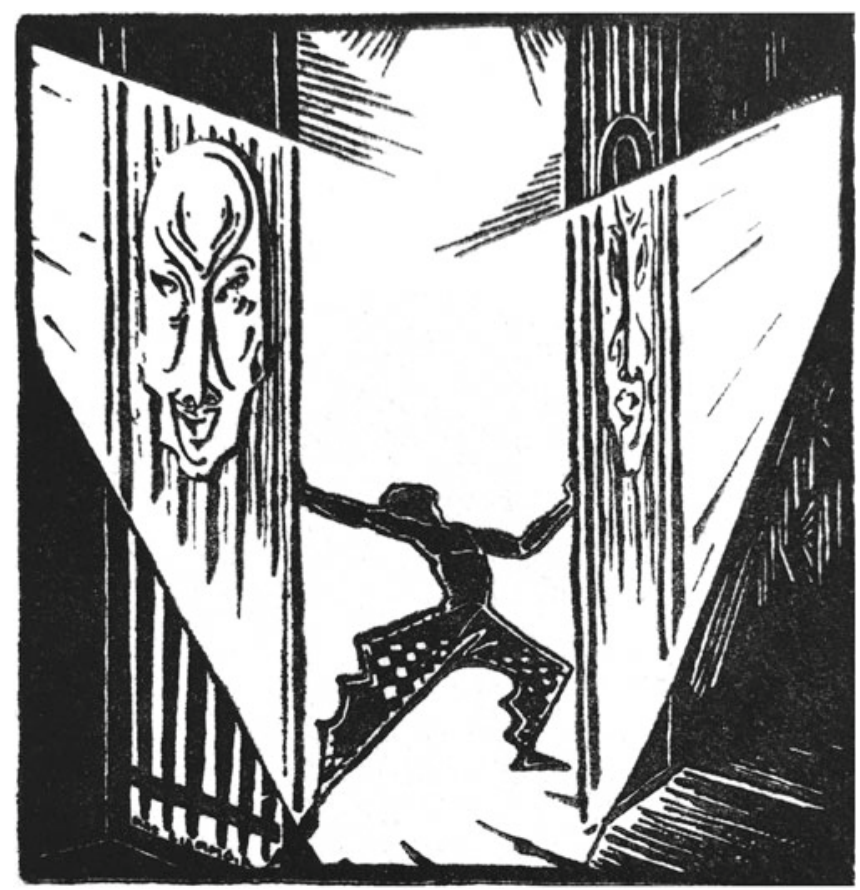

Fig. 5.2 Mac Liammóir's logo created for the Dublin Gate in 1928 (Copyright of the Edwards - mac Liammóir Estate)

of 'eminent theatrical people' that had included Sir Nigel Playfair and William Mollison, but not included Godfrey ('Radio Drama and Music' $8)$. The broadcast was received in Ireland and listed in the Northern Whig and Belfast Post newspaper ('Broadcasting' 10). ${ }^{10}$ According to a report in Theatre Arts published a month before the above article, the editor Edith J. Isaacs represented key points from this unpublished talk in which Pilcher had declaimed how the "newest and youngest aim in theatre is to be theatrical [...] Our ideal is the theatrical theatre' (396). There seems to be an echo of her thinking in what Hilton Edwards called 'the theatre theatrical' writing in Hobson's celebratory volume in 1934 (22), as much as he may have been influenced also by Gray's 1932 article in the Varsity Weekly, 'The Theatre Shall Be Theatrical'. Edwards certainly stated how he was indebted to the vision of Edward Gordon Craig (Pine and Cave 
21-22). Like many contemporaries, Pilcher was also fascinated by Craig; she was friends with his sister, Edy Craig, and met him either with Dame Ellen Terry or at her funeral in Smallhythe Kent which had occurred in July 1928, just before Pilcher met with Edwards. ${ }^{11}$

A key reason why Pilcher's influence on the Dublin Gate has lain hidden is because her role in the London Gate was effectively erased by Godfrey in a new Subscriber's Leaflet produced in late 1928 for calendar year membership from January 1929. This was due to the fact that throughout 1929 he was in dispute with her and forced her out of the partnership. However, the theatre continued to feature the logo, believed to be Pilcher's design, although it was much smaller than the one used in previous publicity, and noted only the new management regime: 'Managers Peter Godfrey Limited', 'Managing Directors Peter Godfrey and Charles N. Spencer' and 'Hon. Sec. Charles N. Spencer'. ${ }^{12}$ Marshall subsequently claimed that he had not known of Pilcher's work at the Gate, which is why he had not included it in his history The Other Theatre (1947). Sprigge reported that in the summer of 1947 he had sent Pilcher a copy of his book which included a section on the London Gate, with 'an apology for it containing no mention of her name. He had not known in time, he explained, of her connection with the Gate Theatre, and had failed to get a last minute addition made to the volume.' (Sprigge 171) It is probable that had Pilcher been remembered by Marshall, had she made contact with him about re-opening the Gate just a few months earlier than she did, in time for him to record her contribution to the establishment of the Gate Theatre Studio in his 1947 book, then her role might have been investigated by historians far earlier and kept her in the story. Although Pilcher is associated with the London Gate in Mander and Mitchison's book The Lost Theatres of London (1968) and her name appears in Allardyce Nicoll's encyclopaedic English Drama, 1900-1930: The Beginnings of the Modern Period, Volume 2 (1973), her presence was unfortunately unacknowledged by Komporaly in her otherwise excellent analysis (140).

\section{The London Gate as a 'Parent' Theatre AND Its Artistic Impetus for Other Theatres}

As it was to Dublin, the London Gate was also a 'parent' theatre to the Hollywood Gate Theatre Studio (Godfrey and others, 1943-1945), 
and the London Watergate Theatre Club (Pilcher and others, 19491952). Various documentary sources, discussed below, connect these other theatres to the London Gate, and illuminate the inspirational qualities of the London Gate Studio Theatre in its Godfrey-Pilcher partnership phase in particular. For example, the new theatre ventures started by Pilcher and by Godfrey used subscribers' publicity materials to express reformulations of the mission of the old Gate for new theatregoers in new contexts. The longer-running success and reputation of the Dublin Gate may equally have influenced the foundation of these 'other' Gates, because of the way they could tap into that sense of a collective avant-garde, modern and internationalist spirit associated with the Gate concept. Theatre Arts Monthly, the American magazine which was subscribed to and read in England and Ireland as well as known in Europe, and which reported on and from Europe and North America throughout its history, referred to developments in all three theatres and reinforced the association of avant-garde identity with the title 'Gate'. ${ }^{13}$

\section{Reorganization in Hollywood: The 'Third Gate 14}

Having sold the London Gate to Marshall in 1934, and after a short period working as compère and magician at the London Pavilion, Godfrey left London for the US in 1937 to act and direct in the American film industry. He thus became one of many European emigrées to move to Hollywood at that time. Godfrey's new venture, directed by two very well-known film actresses - his second wife Renee Godfrey (Haal) and Anita Sharp-Bolster - responded to the central European dimension of transcontinental exile within Hollywood culture. Harold Leonard, critic and film historian, commented on how Godfrey's 'transplanted London Gate Theatre' was 'the one short-lived theatrical project of significance [...] since the dissolution of the W.P.A. Federal Theatre' and was transformative of the rather backward-looking cultural life of Los Angeles as he saw it at that time (39).

The theatre's membership prospectus (1943) announced the theatre as 'reorganized $[\ldots]$ with the same director, Peter Godfrey, and some of the original players from London, united to create again the spirit of free enterprise and experiment, which existed in the Gate Theatres of London and Dublin'. The choice of programme shows Godfrey recalling not only plays he had produced at the London Gate, other London theatres and the Cambridge Festival Theatre, but which had also been performed in 
Dublin theatres. For example, Harley Granville-Barker's translation of Jules Romaine's Doctor Knock had opened in Dublin at the Abbey on 16 February 1926, produced by Lennox Robinson. Godfrey had also produced it at the Royalty Theatre, London on 27 April 1926 (Fig. 5.3).

The Hollywood-located ${ }^{15}$ 'Gate Theatre Studio' was announced in Variety on 22 December 1943 as 'a new coast group' whose 'members act without pay'; the article reported that Godfrey had 'operated similar groups in Dublin and London' (52). It was also announced in rank, the American army weekly (because the Godfreys were active in troop entertainment in wartime), which commented that there were links to

Fig. 5.3 Membership Prospectus for the Gate Theatre Studio, Hollywood, 1943

\section{THE GATE THEATRE STUDIO}

2560 NORTH BEACHWOOD DRIVE, HOLLYWOOD 28, CALIFORNIA GRANITE 9857

\section{A thentre reorganized in Hollywood with the same} director, Peter Godfrey, and some of the original players from London, united to create again the spirit of free enterprise and experiment, which existed in the Gate Theatres of London and Dublin. Plays will be chosen from the following:

\section{MAYA by Simon Gantillon}

DR. KNOCK by Jules Romaine THE GOVERNMENT INSPECTOR by Gogol KING LEAR by William Shakespeare VOLPONE, THE FOX by Ben Jonson THE DREAM DOCTOR by Lenormand AS YOU DESIRE ME by Pirandello

And the plays of Eugene O'Neill, Georg Kaiser, Strindberg, Ibsen, Toller, Saroyan, Sean O'Casey, Garcia Lorca, Aristophanes, Jean Cocteau, James Bridie, Jean Jacques Bernard. 
Ireland amongst the group, as well as several members who had acted at the London Gate, including Aubrey Mather, Vincent Price and Alan Napier ('New Stage Group' 19). Other actors had come from England to Hollywood, such as John Abbott, former member of the Old Vic.

Cast lists for the plays produced likely drew on others from the list of 'founder members' recorded on the back of the programme for Kaiser's From Morn to Midnight, many of whom were indeed Irish and/or have acted in Ireland. ${ }^{16}$ For example, readers of Theatre Arts magazine were informed in an article by George Morris (January 1945) that Anita Bolster was 'a former Abbey Theatre player' (58); she was also Irish-born as Alice Bolster. ${ }^{17}$ In the programme for Simon Gantillon's Maya, which had also been reported on by Theatre Arts ('Maya: The Gate Theatre Studio' 298), it is specifically noted that one of the London Gate's former actresses, who also worked in films, Moyna MacGill, was Irish-born. She was playing the lead role - Maya - in this production, although she had not done so when it had been first performed as the opening play of the Gate Studio in London (she had, however, played Eurydice in the 1928 production of Orphée). ${ }^{18}$ Also Irish-born was Barry Macollum who played a Sidi. J.M. Kerrigan, Irish character actor and member of the Abbey Players from 1907, until he left to become a film actor in Hollywood, acted the role of Doctor Parpalaid in the production of Romaine's Doctor Knock in 1944. ${ }^{19}$ Sara Allgood, who had had a prominent career at the Abbey Theatre, is also listed as a founder member; however, it is not known whether she actually acted at the theatre.

In a note - 'The Gate Theatre Is a Year Old' - printed in the programme for Doctor Knock, which was the third production of the new Gate, links were drawn to its relationship to other Gates and particularly to the continuing success of the Dublin theatre. Audiences were informed that 'the original Gate was founded in London, by Peter Godfrey' (without mention of Molly Veness), and that he 'produced and directed one hundred and ten of the world's most famous plays, first in Covent Garden and later at the larger Gate in Villiers Street' (without mention of Velona Pilcher or Charles N. Spencer). It is curious that from the 1945 Theatre Arts article by Morris it appears that the London Gate is still operational, perhaps because he is writing in the present tense. In fact, it had been put completely out of action and Morris's comment does not compare to the statement in the theatre's programme for Doctor Knock (which he may not have seen) that the London Gate had been destroyed in the Blitz in June 1941. As the Hollywood theatre only opened in 
1943, it seems most likely that Morris is using the historical present tense, seeking to convey that the spirit of the Gate Theatre London and its association with modernity had continuing significance; he may be choosing to see the London Gate as a contemporary rather than historical phenomenon, implying that Godfrey was actively connected to the London theatre still, as he was adapting his London experiences to 'the Hollywood problem'. The reference to a 'genie' here is to Godfrey in his role as conjuror for the troops during the war, for which he was very well-known:

Roughly speaking, as distances go, it is a good six thousand miles from Charing Cross in London to Beachwood Drive in Hollywood. Yet confirmed theatregoers in both places find themselves greeted by the identical legend: Gate Theatre Studio. This is not the work of a magic genie shuttling back and forth across the Atlantic with the speed of light, but the doing of a dynamic, enthusiastic individual who loves his theatre, Peter Godfrey. (58)

Morris also elaborated on the status of the theatre, information on which appeared in the Doctor Knock programme as well: he asserts that '[1]ike the London and Dublin namesakes, the Hollywood Gate is non-profit', meaning 'non-commercial', and '[n]obody was to be paid to act and no acting fee was required' (59). However, this was not in fact wholly true of the practices of these other theatres through their life cycles.

The programme note for the American production of From Morn to Midnight from March 1944 acknowledged the significance of this important work of the modernist avant-garde across Europe and America by saying 'it has been played in nearly all languages in all the important capitals of the world'. Morris's article carried a photograph of Godfrey performing as the cashier by Man Ray, who had arrived in Los Angeles from Paris in 1940, and had also photographed Maya for Theatre Arts the year before. Peter Godfrey had directed the first British production of the Kaiser play at the original Gate Theatre Salon in 1925, as well as productions at both the Cambridge Festival Theatre and The Gate Theatre Studio London in 1928, and a revival at the same venue which opened on 3 May 1932. The programme also carried a message from another emigré, Thomas Mann, who expressed his happiness that 'American audiences are being made familiar' with Kaiser's works and sent his best wishes to the cast of the new theatre (3). Mann had been honoured by several 
American universities and by the National Library of Congress, and was acknowledged as a leader amongst the German exiles. Additionally, he championed the cause of refugees and offered considerable practical assistance. To have Mann's endorsement for a theatre company producing a German classic of pre-war expressionism which included emigré actors was highly significant and revealed the high calibre and serious intent of the endeavour at Brentwood Drive. Mann was well-established in Southern California in the 1940s, visitor to the Feuchtwanger and Viertel Salons in Santa Monica frequented by artistic and theatrical people, where inter-war Weimar German 'discourse resurfaced' and this context likely supported the theatre membership (Fear and Lerner 2). Ultimately, this multicultural American Gate Studio Theatre closed quickly due to sudden expiry of its lease; it had survived for over three years. ${ }^{20}$

\section{Continuing the Policy of the Gate Theatre at the Watergate Theatre Club}

Sprigge's biography records how Pilcher tried and failed to re-open the Gate Theatre London after the war. In winter 1946, Pilcher apparently wrote to Marshall 'to ask him the exact position in regard to the Gate' and apparently then had 'discussions with Norman Marshall and other advisers' about whether she could revive the Gate (65). Sprigge noted the result of these conversations from Pilcher's journal: "“The Gate is open”, [Pilcher] recorded, when Marshall told her that if he did not restart the Gate theatre himself, which was unlikely, she undoubtedly had the next right to the name.' (158) Presumably, Marshall thought this was in his gift, because he had bought Godfrey out in 1934. Sprigge recalled the visit she and Pilcher made to where the old Gate used to stand in quite romantic terms:

We made a pilgrimage to the site then, one early evening under a rosy sky, black-patterned with starlings, and Velona saw a footprint engraved on the pavement, pointing towards the theatre. This she took as a favourable portent, nor was she perturbed by the great pile of rubbish in the open door. We climbed over feet of rubble and explored the shell of the auditorium, the stage and the tiny dressing-rooms, and then Velona rang up her solicitor, ${ }^{21}$ told him that everything of the old Gate was there but the roof and instructed him to try to get the premises for her. (158) 
It seems most likely that the site was actually in too bad a state, but it is unclear why the idea could not work out. Sprigge did note how in 1948 when they were still looking for a theatre venue, 'examining all possible premises', that 'the old Gate was scheduled to be yet one more café in that street of cafés' (180). Pilcher had considered how she might make a Gate 'barn theatre' at her farmhouse 'Shotters' near Lodsworth, emulating the example of the Terry/Craig theatre at Smallhythe Kent, and between May and Autumn 1947 had discussed her vision for such a new Gate with her friends actor Alan Wheatley and producer David Tutaev (169). Nothing came of this attempt to make a new Gate as a barn theatre either as in 1948 the farm was first let and then sold. At the request of Tutaev, Pilcher formed an alliance with him and Sprigge that led, in summer 1948, to the foundation of the 'Forty-Eight Theatre Company' based at the Anglo-French Arts Centre in London, which had been founded by Alfred Rozelaar Green in the old St. John's Wood Art School in 1946 (Sprigge 172, 174). Although Pilcher still wanted to have her own theatre, working with this company was her first attempt 'to provide a worthy successor to the Gate Theatre' (Sprigge 177). On 8 June 1948, The Times reported the news that this company was a 'playproducing society', 'a non-profit-making limited liability company' which hopes 'eventually to have its own company in its own theatre' ('New Play-producing Society' 7). The policy was to produce new British and American work and recent foreign works in new translations. It was an ambitious new set-up for an arts centre with lectures, late night revue, rehearsals, classes, and even 'experiments' listed in the news article.

Sprigge asserted that Pilcher had reflected in her journal on a new Gate with an artistic vision as an experimental theatre, which she believed could be 'the theatre of truth' (173). Pilcher was a follower of the teaching of Gurdjiev and a member of Maurice Nicol's group, and her thinking about art was imbued with spirituality. In her Theatre Arts essay 'Testament of Theatre' (1947), apparently a summary of a planned book, she conceptualized an interdisciplinary imaginative avant-garde. Later, in 1949, an extract from this vision was reproduced on the marketing materials for the Watergate Club: 'Avant-garde $-[\ldots]$ really means the prophetic sense - the feeling forward into the next step [...] - the going forward - This is it. The opening. The way of Wings - up above the worming theatre way [...] The aim of all these ideas is not to bring the best of all the other arts into the theatre so much as to bring the theatre into line with the best in the other arts.' (qtd from Sprigge 174-75) 
Pilcher and Sprigge were looking for their own theatre at the same time as Forty-Eight Theatre and David Tutaev sought to go their own way. The Watergate premises had been renovated by architects Elizabeth Denby and Jane Drew who had obtained a lease from the London County Council and converted it from a restaurant on the North Embankment of the Thames, naming it after the York Watergate built by Inigo Jones in 1626. This new conversion was located a stone's throw from the old Gate. During the planning phase, there was a series of meetings between the four board members (Drew, Denby, Pilcher and Sprigge) and the group overseeing the foundation and early management of an Institute of Contemporary Arts in London, which still exists as the 'I.C.A'. A collaboration was proposed by the I.C.A. group who intended to promote contemporary theatre as part of their scheme. A rehearsed reading of the Picasso play Desire Caught by the Tail at the London Gallery arranged by Roland Penrose in 1947, who was later on the joint committee, probably began the discussion about a relationship, as this was a play that the Watergate went on to stage in 1950. Herbert Read, who was also involved in setting up the I.C.A., had been a supporter of the Forty-Eight Theatre and had chaired the first general meeting at the St. John's Wood AngloFrench Arts Centre. Pilcher was present at some of the joint I.C.A and Watergate Theatre meetings, invited to represent artistic policy for the Watergate group, including a proposed programme which was strongly international. There was open debate about her ideas, but the I.C.A. also invited other theatre representatives. It struggled to get the participation desired from Michel St. Denis and the Group Theatre, and finally Peggy Ashcroft expressed doubts about the Watergate directors' inexperience. On 2 June 1949, the minutes recorded: 'Miss Pilcher said that artistic policy must be agreed between the I.C.A. and the Watergate. The Watergate's aim was to continue the policy of the Gate Theatre, and its directors would want to be satisfied that the I.C.A. was in agreement with this.' (4) The committee attempted to micro-manage the arrangements for the new theatre in terms of appointing staff but conflicts quickly arose concerning the commercial basis that the club needed to operate on, with income from catering or expenses of room hire factored in. Jane Drew (who by 1949 had taken over as the Chairman of the joint I.C.A. and Watergate committee) decided to withdraw from the Watergate theatre project in late August 1949 (Institute of Contemporary Arts - Watergate. Minutes 25 August 1949). Ultimately, the proposed collaboration failed to establish and the Watergate opened independently. The three 
remaining women of the Watergate group - Pilcher, Sprigge and Denby - formed a public limited company (Thameside Productions) in order to run the theatre, and finally opened it as a members' club on 19 December 1949.

To Pilcher and Sprigge, the Watergate was the London Gate reborn. A publicity leaflet released 1949 to promote the purchase of season tickets to subscribers promised 'a small avant-garde theatre-club in the heart of London for the practice and enjoyment of the arts', and is not dissimilar from the Gate Studio mission. Although another small stage, it had club rooms and a restaurant which enabled Pilcher to develop the plans for lectures, a newsletter, exhibitions and cuisine, all of which she had moved forward with at the old Gate but could not fully carry out due to the collapse of the partnership with Godfrey. Some connections can be seen between the Watergate's artistic policy and that of the old Gate. For example, a new translation of Kaiser's last play Medusa's Raft (1940-1943; first produced 1945) was staged on 26 January 1950, thus extending the association with Kaiser whose work had been so strongly cemented to the history of the London Gate. Cocteau's The Typewriter (14 November 1950) was chosen and mirrored the production of his Orphée that Pilcher had previously brought to the London Gate. $^{22}$ More emphasis was placed on new playwrights than at the old Gate. Pilcher invited the American Paul Green to a Watergate party to discuss new work; his play The Field God had been produced at the Etlinger School Theatre under the auspices of The Gate Theatre Studio (30 September 1927). Young British writers Anne Ridler, Ronald Duncan, David Gascoyne and Philippa Burrell were all supported with performances, and there was a strong European dimension to the wider planning of talks, films, and exhibitions.

Writer Nancy Cunard, Pilcher's cousin, who herself hoped for a production of a translation she had made of Ramón del Valle-Inclán's Ligazon (1926) (a plan that did not come to fruition), ${ }^{23}$ publicized the revival of the Gate ideal by praising the open nature of little theatres 'which are always brave ventures' in an article for Life and Letters and the London Mercury. This explored the creative mindset of the group of the Watergate founders (Cunard 239). Cunard introduced Pilcher's past in brackets, saying she was '(already well-known as a founder-director of the Gate Theatre when it opened in Villiers Street)', and emphasized that she was well-connected to contemporary culture due to cultivating the 
'friendship of several famous artists' involved in the venture (238-39). The Watergate was an influential and successful club theatre which had a particularly global outlook. It became a site for international communication featuring Eric Bentley on Brecht, Peter Brook and Ram Gopal, and brought the first cabaret group from Germany after the war. Denby retired from the management team 'owing to ill-health' in May 1951 (Sprigge 197). The club carried on for a few years after Pilcher's death in 1952 under new management. In 1953, The New Statesman and Nation magazine reported: 'The New Watergate Theatre Club is now, on its stage side, under the direction of Mr. Norman Marshall who, it will be remembered, supplied the serious theatre-goer with many of his pleasures between the wars at the old Gate.' (486) In 1956, the original premises at 29 Buckingham Street were forced to close due to the widening of The Strand. Muriel Large, the manager, reopened the club at the Comedy Theatre held on lease by Anthony Field, where 'New Watergate Productions' quickly attracted many thousands of members and the new version of the theatre became a highly significant player in the abolition of censorship.

\section{CONCLUSION}

The concept of convergence is helpful in pinpointing concurrences in the missions and cultural achievements of this connected network of experimental theatres, specifically with respect to their internationalist outlooks, overlapping associations of management and production personnel, as well as performers. Parallels can be drawn between their similar artistic and collaborative club cultures. Although there was very limited artistic traffic between the London and Dublin Gate Theatres compared to what had initially been envisaged, there are many associations embedded in the historical record shown in the network of connections traced here. Tracking the involvements of a small number of key individuals opens up a range of interrelations through which it is possible to trace influence. The diversity of people involved with the Hollywood Gate who brought associations from Europe into American culture was exceptionally wide for such a small and short-lived venture, and explains how it was possible for Godfrey to succeed with his recreation of the Gate Studio there. The involvement of Sprigge at the Watergate, who had previously been in the audience at the Gate Studio, and then Marshall who had reshaped the Gate and later took over the Watergate, a few years after Pilcher had left 
each organization, also evidences intriguing links in the pattern of involvements across theatres. The connected history of Gate Theatres was made up of shared qualities in theatre practice characteristic of the international little theatre movement. The theatres discussed in this chapter are sometimes called 'fringe' without clarity of what they were on the fringe of. ${ }^{24}$ They are more plausibly viewed rather as examples of 'pre-fringe' theatre venues, prefiguring the emergence of the 'fringe' before 1947, when that term was first used at the Edinburgh International Festival, although it only became more widespread in the 1960s (Chambers 2011, 332, $334)$. Such theatres can most productively be termed 'theatres of art', following the designation deployed by Katharine Cockin in her biography of Edith Craig: 'diverse', 'independent' and 'small-scale' with an openness in artistic policy which stemmed from an anti-commercial stance, rather than merely 'other' (as Marshall would have it) or 'alternative' (according to Davies) (Cockin 2).

\section{Notes}

1. For example, Pilcher had run a recreation hut in an American army hospital just behind the front line in World War I. Further information is available in Purkis 2016a.

2. I have written outlines about this professional partnership elsewhere; see Purkis 2011 and 2016b.

3. For example, the unsigned programme note for Eugene O'Neill's All God's Chillun (20 November 1928) ends with words very similar to those reported by Isaacs in Theatre Arts Monthly (1929) from Pilcher's BBC broadcast of the same month concerning ideal theatre: 'The Gate Theatre itself belongs to the little theatre movement. It respects the playwright, who is the first theatrical craftsman, and seeks to offer him his creative hearth. It even respects the critic, who can interpret the theatrical movement if he will.' ('A Note on Eugene O'Neill') Programme notes in the 1927-1928 season were signed 'V.P'.

4. Sisson had used the term 'homage' to describe the relationship between the London Gate and the new Dublin theatre in an earlier version of her 2011 essay and emphasized how the Dublin Gate sought to be as 'equally daring and experimental' as London (2010, 139).

5. Colin Chambers in the Continuum Companion to Twentieth-Century Theatre has claimed that the name and spirit were taken up by the small theatre with the same name in West London (303). But in fact, the current Gate Theatre London based in Notting Hill is completely independent of the original Gate. This has been confirmed by Lise Bell, 
Executive Director, to the author: 'We don't have any connection other than by name with the Gate in Dublin or other Gates of the past. I know there's a Wikipedia article or two that suggests we do, but we were established as our own entity.' (Email to the author, 29 July 2019.) See also: https://www.gatetheatre.co.uk/about-us/our-story.

6. Details are available in Luke 13-14, 93.

7. It is not known whether Godfrey was present in the audience in Dublin.

8. The London Gate is perceived as losing its experimental edge under the directorship of Marshall, after a few years in decline in the final years under Godfrey, although Sprigge is more generous about the period after Pilcher left. See, for example, Banham and Stanton (136).

9. Sprigge inherited all of Pilcher's papers on her death in 1952; she also had the benefit of conversation from their initial meeting in 1944 until Pilcher's death because the two were partners. Pilcher's early death at the age of fifty-eight from cancer, which she had been treated for over a number of years, makes it likely that the two conversed about Pilcher's earlier life with the expectation that Sprigge, an established biographer, would become the custodian of her story.

10. Pilcher had previously published in this Irish newspaper in 1923, at the time Cochran was producing a Eugene O'Neill cycle of plays in London at the Strand Theatre. Although her article may not have been read by Edwards, it is possible that they discussed her experience at the Provincetown Playhouse in Greenwich Village when they met in 1928, and she may have shared the article with him.

11. For further context, see Purkis 2011, which discusses her relationship with this group.

12. The logo ceased to be used on the new notepaper for the Godfrey-Spencer partnership, adding further to the speculation that it was a design made by Pilcher herself. It was routinely used on her letters sent from the theatre to artistic associates and is retained in various archival collections.

13. The first article on the Dublin Gate in the magazine was Macardle's in 1934.

14. Expression used on p. 3 of the programme for Doctor Knock.

15. 2560 North Beachwood Drive, Hollywood 28, California is now the location of the Besant Lodge liberal Catholic Church. The site is less than an hour's drive from Velona Pilcher's teenage home at Long Beach.

16. Archival copies of the programmes for the other productions have not yet been traced.

17. At this time, she was also known as Anita Sharp-Bolster - using her surname by birth - and was the elected Dean of the Drama department of the newly-created Hollywood Academy of Arts. For further information, see Nissen (178). 
18. Barbara Roisman Cooper recalls her mother working on Maya with Edgar Bergen and Peter Godfrey, and that she had been in the audience for the 'Beachwood Theatre on Beachwood Drive in Hollywood' (238). This was the theatre used by Godfrey, by its former name after its location.

19. Archival evidence is incomplete.

20. Phyllis Hartnoll erroneously listed it as opening in 1944 in The Concise Companion to the Theatre (201).

21. The playwright Harold F. Rubinstein.

22. A translation by Pilcher of Cocteau's The Marriage at the Eiffel Tower was also proposed to the ICA/Watergate joint committee as one of the plays for the Watergate, but this was not produced and the translation is lost, assuming it had been completed.

23. Full context is discussed in Pereiro-Otero.

24. For instance, J.C. and Wendy Trewin state in their book on The Arts Theatre that '[d]uring the mid-1920s the word Fringe was unused' (1).

\section{WORKS CITED}

'A Note on Eugene O'Neill'. 1928. Programme for Eugene O'Neill, All God's Chillun. The Gate Theatre Studio, London, 20 November.

Banham, Martin, and Sarah Stanton. 1996. The Cambridge Paperback Guide to Theatre. Cambridge: Cambridge University Press.

Bishop, G.W. 1927. 'A Youthful Producer'. The Era, 7 September, 5.

'Broadcasting. Programmes for Today: Belfast-2BE'. 1928. Northern Whig and Belfast Post, 21 November, 10.

Cave, Richard Allen. 2011a. Collaborations: Ninette de Valois and William Butler Yeats. London: Dance Books.

Cave, Richard Allen. 2011b. 'Staging Salome's Dance'. In Refiguring Oscar Wilde's Salome. Ed. Michael Y. Bennett, 145-66. Amsterdam and New York: Rodopi.

Chambers, Colin. 2002. Continuum Companion to Twentieth-Century Theatre. London: Bloomsbury.

Chambers, Colin. 2011. 'Fringe Theatre Before the Fringe'. Studies in Theatre o Performance 31.3: 327-38.

Cockin, Katharine. 2017. Edith Craig and the Theatres of Art. London: Bloomsbury.

Connolly, Thomas F. 2010. Genus Envy: Nationalities, Identities, and the Performing Body of Work. New York: Cambria Press.

Cowell, John. 1988. No Profit but the Name: The Longfords and the Gate Theatre. Dublin: O'Brien Press.

Cunard, Nancy. 1950. 'The Watergate Theatre'. Life and Letters and the London Mercury 65 (June): 238-41. 
Davies, Andrew. 1987. Other Theatres: The Development of Alternative and Experimental Theatre in Britain. Basingstoke: Macmillan.

Dean, Joan FitzPatrick. 2004. Riot and Great Anger: Stage Censorship in Twentieth-Century Ireland. Madison, WI: University of Wisconsin Press.

'Denis Johnston Reviews Gate Theatre History'. 1953. Irish Times, 3 December, 5. Dorman, Sean. 1992. Portrait of My Youth. Fowey: Raffeen Press.

Dukes, Ashley. 1928. 'Standing Room Only: Maya at The Gate Theatre'. Theatre Arts Monthly 12.2: 140-45.

Dukes, Ashley. 1930. 'The Irish Scene: Dublin Plays and Playhouses'. Theatre Arts Monthly 14.5: 378-84.

Edwards, Hilton. 1934. 'Production'. In The Gate Theatre Dublin. Ed. Bulmer Hobson. Dublin: The Gate Theatre.

'Edwards and Mac Liammoir: We Must Be Talking'. 1973. In Des Hickey, and Gus Smith. Flight From the Celtic Twilight. Indianapolis and New York: Bobbs-Merrill.

Ervine, St. John. 1931. 'The Plight of the Little Theatre'. Theatre Arts Monthly 15.7: 538-46.

Fear, Jeffrey, and Paul Lerner. 2016. 'Behind the Screens: Immigrants, Émigrés and Exiles in Mid-Twentieth-Century Los Angeles'. Jewish Culture and History 17.1-2: 1-21. https://doi.org/10.1080/1462169X.2016.1190496. Accessed 8 January 2020.

'From the Irish Capital'. 1929. Derry Journal, 13 March, 3.

Girel-Pietka, Virginie. 2018. 'Denis Johnston at the Gate: A Groundbreaking Yet Neglected Writer'. In The Gate Theatre, Dublin: Inspiration and Craft. Eds David Clare, Des Lally, and Patrick Lonergan, 111-30. Oxford and New York: Peter Lang/Carysfort Press.

Gray, Terence. 1932. 'The Theatre Shall Be Theatrical'. The Varsity Weekly, 8 January, 2.

Grein, J.T. 1927. 'The World of the Theatre'. The Illustrated London News, 24 September, 192.

Grene, Nicholas, and Chris Morash, eds. 2005. Irish Theatre on Tour. Dublin: Carysfort Press.

Hartnoll, Phyllis. 1988. The Concise Companion to the Theatre. London: Omega Press.

Hobson, Bulmer, ed. 1934. The Gate Theatre Dublin. Dublin: The Gate Theatre.

Hogan, Robert. 1967. After the Irish Renaissance: A Critical History of the Irish Drama since The Plough and The Stars. Minneapolis, MN: University of Minnesota Press.

Hogan, Robert. 1978. Untitled Contribution. In Enter Certain Players: EdwardsMacLiammoir and the Gate 1928-1978. Ed. Peter Luke, 13-18. Dublin: Dolmen Press.

Institute of Contemporary Arts-Watergate. Minutes of a Committee meeting held at 5 pm on Thursday, 25 August 1949, at 12 Bedford Square. Typescript. 
Institute of Contemporary Arts-Watergate. 'Possible Collaboration between the Institute of Contemporary Arts and the Watergate Theatre'. Minutes of a Committee meeting held on Thursday, 2 June, 1949. Typescript.

Isaacs, Edith J. 1929. 'Velona Pilcher Defines Ideal Theatre'. Theatre Arts Montbly 13.6: 395-97.

'Johnston: Did You Know Yeats? And Did You Lunch with Shaw?' 1973. In Hickey, Des, and Gus Smith. Flight From the Celtic Twilight. Indianapolis and New York: Bobbs-Merrill.

Komporaly, Jozefina. 2011. 'The Gate Theatre: A Translation Powerhouse on the Inter-war British Stage'. Journal of Adaptation in Film and Performance 4.2: $129-43$.

Leonard, Harold. 1945. 'Hollywood Is Interested in Culture'. Sight and Sound 14.54: 39-42.

Levitas, Ben. 2014. 'Modernist Experiments in Irish Theatre'. In The Cambridge Companion to Irish Modernism. Ed. Joe Cleary, 111-27. Cambridge: Cambridge University Press.

Luke, Peter, ed. 1978. Enter Certain Players: Edwards-Mac Liammoir and the Gate 1928-1978. Dublin: Dolmen Press.

mac Liammóir, Micheál. 1946. All for Hecuba: An Irish Theatrical Autobiography. London: Methuen and Co.

Macardle, Dorothy. 1934. 'Experiment in Ireland'. Theatre Arts Monthly 18.2: 12433.

Madden, Tom. 2015. The Making of an Artist: Creating the Irishman Micheal MacLiammóir. Dublin: The Liffey Press.

Mander, Raymond, and Joe Mitchison. 1968. The Lost Theatres of London. London: Hart Davis.

Marshall, Norman. 1947. The Other Theatre. London: Lehmann.

'Maya: The Gate Theatre Studio'. 1944. Theatre Arts, 28 May, 298.

Membership Prospectus. 1943. The Gate Theatre Studio, 2560 North Beachwood Drive, Hollywood 28, California.

Meyers, Jeffrey. 2012. 'Thomas Mann in America'. Michigan Quarterly Review 51.4. http://hdl.handle.net/2027/spo.act2080.0051.419. Accessed 8 January 2020.

Morash, Christopher. 2002. A History of Irish Theatre 1601-2000. Cambridge: Cambridge University Press.

Morris, George. 1945. 'From Gate to Gate'. Theatre Arts 29.1: 58-61.

Murray, Christopher. 2004. Seán O'Casey: Writer at Work. Dublin: McGill and Macmillan.

'New Coast Group'. 1943. Variety, 22 December, 52.

'New Play-Producing Society'. 1948. The Times, 8 June, 7.

'New Stage Group'. 1943. Yank 1.41: 19. 
'New Watergate Theatre Club'. 1953. New Statesman and Nation Magazine, 24 October, 486.

Nicoll, Allardyce. 1973. English Drama, 1900-1930: The Beginnings of the Modern Period, Vol. 2. Cambridge: Cambridge University Press.

Nissen, Axel. 2016. Accustomed to Her Face: Thirty-Five Character Actresses of Golden Age Hollywood. Jefferson, NC: McFarland and Co.

Ó hAodha, Micheál, ed. 1980. The O’Casey Enigma. Dublin and Cork: The Mercier Press.

Ó hAodha, Micheál. 1990. The Importance of Being Micheál: A Portrait of MacLiammóir. Kerry: Brandon Book Publishers.

'Obituaries: Peter Godfrey'. 1970. Variety, 11 March, 79.

'Obituary: Peter Godfrey'. 1970. The Stage and Television Today, 19 March, 11.

Pereiro-Otero, José Manuel. 2010. Vanguardia, exilio y traducción en las posguerra europeas: Nancy Cunard y Ramón del Valle-Inclán. Madrid: Editorial Verbum.

'Peter Godfrey: Biographical Sketch'. 1947. Genii: The Conjurer's Magazine 11.11: 345 .

Pilcher, Velona. 1923. 'The Provincetown Players: Theatrecraft in the New World'. Northern Whig and Belfast Post, 31 March, 8.

Pilcher, Velona. 1929. 'All Work and No Play'. Theatre Arts Monthly 13.7: 506-16.

Pilcher, Velona. 1947. 'Testament of Theatre'. Theatre Arts 31.3: 45-47.

Pine, Richard, and Richard Allen Cave. 1984. The Dublin Gate Theatre, 1928-78. Cambridge: Chadwyck-Healey.

'Plays of the Month'. 1932. Drama: A Monthly Record of the Theatre in Town and Country, at Home and Abroad-The Journal of the British Drama League 11.2: $18,29$.

Programme for Georg Kaiser, From Morn to Midnight. 1944. Gate Theatre Studio, Hollywood, 28 March.

Programme for Jules Romaine, Doctor Knock. 1944. Gate Theatre Studio, Hollywood, 16 September.

Purkis, Charlotte. 2011. 'Velona Pilcher and Dame Ellen Terry (1926)'. In Ellen Terry, Spheres of Influence. Ed. Katharine Cockin, 119-32. London: Pickering and Chatto.

Purkis, Charlotte. 2016a. 'Velona Pilcher's "Literary Excursions" in the Theatre of War'. In Literary Journalism and World War I: Marginal Voices. Eds Andrew Griffiths, Sara Prieto, and Soenke Zehle, 181-206. Nancy: PUN Editions Universitaires de Lorraine.

Purkis, Charlotte. 2016b. 'Velona Pilcher's Promotion of an Intercontinental Theatrical Avant-Garde'. In Intercontinental Crosscurrents: Women's Networks Across Europe and the Americas. Eds Julia Nitz, Teresa Schoen, and Sandra H. Petrulionis, 71-90. Heidelberg: Winter Verlag.

'Radio Drama and Music'. 1929. The Era, 16 January, 8. 
Roisman Cooper, Barbara. 2015. Great Britons of Stage and Screen: In Conversation. Lanham, MD: Rowman \& Littlefield.

Rowan, Terry. 2015. Who's Who in Hollywood. Lulu.com.

Rowell, George, and Anthony Jackson. 1984. The Repertory Movement: A History of Regional Theatre in Britain. Cambridge: Cambridge University Press.

Sisson, Elaine. 2010. "'A Note on What Happened": Experimental Influences on the Irish Stage, 1919-1929'. Kritika Kultura 15: 132-48.

Sisson, Elaine. 2011. 'Experimentalism and the Irish Stage: Theatre and German Expressionism in the 1920s'. In Ireland, Design and Visual Culture: Negotiating Modernity, 1922-1992. Eds Linda King and Elaine Sisson, 39-58. Cork: Cork University Press.

Sorley Walker, Kathrine. 1987. Ninette De Valois: Idealist Without Illusions. London: Hamish Hamilton.

Sprigge, Elizabeth. n.d. 'L'Idiote Illuminée: The Life and Work of Velona Pilcher'. Typescript. Copies held at The Edmund Duncan Rubbra Archive, special collections, Bodleian Library Oxford, and in the author's private collection. Quoted by permission of Elizabeth Lumley-Smith.

'Subscriber's Leaflet'. 1927. The Gate Theatre Studio, London, Autumn.

'Subscriber's Leaflet'. 1929. The Gate Theatre Studio, London, January.

'Ten Years of the Gate Theatre: What It Has Done for Drama'. 1939. Irish Times, 21 January, 192.

'The Gate: Peer Gynt'. 1932. The Stage, 20 October, 12.

'The Gate Theatre: Failure of a London Enterprise'. 1933. Manchester Guardian, 10 August, 10.

Trewin, J.C. 1960. The Turbulent Thirties: A Further Decade of the Theatre. London: Macdonald.

Trewin, J.C., and Wendy Trewin. 1986. The Arts Theatre London, 1927-1981. London: The Society for Theatre Research.

Walsh, Ian R. 2018. 'Hilton Edwards as Director: Shades of Modernity'. In The Gate Theatre, Dublin: Inspiration and Craft. Eds David Clare, Des Lally, and Patrick Lonergan, 29-46. Oxford and New York: Peter Lang/Carysfort Press.

World Biography, Vol. 5. 1954. New York: Institute for Research in Biography. 
Open Access This chapter is licensed under the terms of the Creative Commons Attribution 4.0 International License (http://creativecommons.org/licenses/ by/4.0/), which permits use, sharing, adaptation, distribution and reproduction in any medium or format, as long as you give appropriate credit to the original author(s) and the source, provide a link to the Creative Commons license and indicate if changes were made.

The images or other third party material in this chapter are included in the chapter's Creative Commons license, unless indicated otherwise in a credit line to the material. If material is not included in the chapter's Creative Commons license and your intended use is not permitted by statutory regulation or exceeds the permitted use, you will need to obtain permission directly from the copyright holder.

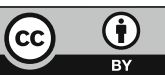

